\title{
COVID 19 Influence on Teaching Process for Children with Disabilities
}

\author{
Tamara Milic \\ Ministry of Education, Podgorica, Montenegro \\ Email address: \\ milic.tamara@gmail.com

\section{To cite this article:} \\ Tamara Milic. COVID 19 Influence on Teaching Process for Children with Disabilities. Education Journal. \\ Vol. 9, No. 5, 2020, pp. 142-148. doi: 10.11648/j.edu.20200905.14
}

Received: August 14, 2020; Accepted: September 8, 2020; Published: October 12, 2020

\begin{abstract}
Research has been conducted to find how isolation affected their competencies: progress, regression, areas need to be strengthened, approaches need to be used, how to plan further work. As an instrument, were used the Assessment Protocol. Strategies and approaches used in working with the child were evaluated, then, assessment of developmental areas of progress and regression in children. After that, academic and developmental progress and regression. This was followed by an assessment of the areas in which the child needs to work additionally. 43 children were assessed and are dominated by intellectual and autism spectrum disorders, which correspond to the general education inclusive context. Findings show that teachers mostly worked and communicated via viber, less through platforms and applications. They were based on the adaptation and individualization of teaching and working materials prescribed by the IDEP done for each child. We find that teachers know the didactic material significantly, but that some resources have not been used to a sufficient, justified and desirable extent - Daisy textbooks and assistive technology. The emotional status of the child was relatively maintained thanks to a more individualized approach. Behavior, interaction and communication are the developmental areas in which in a significant number of children happened attachment, awareness because that they have enjoyed an individualized teacher orientation. But, it is at the same time estimated the presence of regression in this area. Quality of knowledge has been achieved in accordance with the reduced content and expectations. Especially affected are practice and application because the teaching took place at home, not in a structured school environment, so this is an area that should be emphasized in the future. Therefore, after the school beginning, the principle of individualization should be maintained, taking into account the characteristic of child disability, his potentials, and appropriate methods of work especially in areas where the child needs support. Intensive work should be done on the catch up activities and materials, practical application, socialization, interaction, communication in a real context.
\end{abstract}

Keywords: COVID 19, Students with Special Educational Needs, Inclusion, Individualization

\section{Introduction}

Covid 19 pandemic happened as an unexpected event that disrupted everyone's usual rhythm of life, work, learning, socializing, and pursuing hobbies. In this context, the additional sensitivity of children with disabilities should be considered. They recognize experience, understand, and express situations like Covid - 19 in various, often unique, unusual and specific ways. This affects understanding, behavior, interactions, the way they spend their time at home [15].

Covid 19 puts inclusive values to a special test: recognizing, responding to diverse needs, involvement, and participation of children. In regular circumstances, through inclusive education, teachers, kindergartens and schools adapt the way they work to the needs of children.

Inclusive education takes place through a flexible approach to teaching, according to structured strategies of the education system [8].

Support makes all activities that increase the ability, and relate to any modification or adaptation: physical environment, educational and curriculum, didactic tools and materials, methods of work, daily schedule and the like. [1]

The Individual Development-Educational Program (IDEP) is a written document developed for each child and covers the area of academic and non-academic knowledge and 
skills. Ways of support, adjustment of the learning process, fulfillment of individual needs and potentials of the child are determined [9].

In working with children with intellectual disabilities, simple, concrete and obvious means are recommended [2].

Visual, written means are recommended when working with children with hearing impairments [11].

In working with children with visual impairments, tactile and means that have enhanced sensory stimulation are recommended [6].

For children with autism there are structures, visual, augmentative support [7].

Assistive technologies are a set of instruments, aids and devices that children with disabilities use to perform tasks that they would not be able [5].

Augmentative communication describes the means used to improve inefficient speech communication [4]

Picture Exchange Communication System (PECS) functioning in a way that child express his needs by giving a picture to his communication partner [3]

DAISY is a multimedia edition of printed books, and the audio-visual text offers a reading experience to all students who for any reason cannot read the text [10].

The situation caused by the Covid - 19 required support in the further development and learning of children with special educational needs that took place at home. For these students, teachers adapted and prepared individualized teaching material in accordance with the IDEP. They made the material available in a way that suits the child and the parents. In order to make easier work of teachers, the school portal for inclusive education posted material that served as a model for teachers to prepare IDEP based individualized material [12].

\section{Methodology}

In order to determine the current developmental and academic status of children with special educational needs, we conducted a research.

We considered that it is important to assess: impact, consequences: whether there was progress or regression, in which areas the potentials should be strengthened, in which compensation is needed and based on that plan further work.

It is assumed that isolation affected the quality of knowledge and everyday competencies of students. That the greatest progress in the emotional relationship (with parents, but also with teachers) is primarily due to individualization, that the decline is in interaction, skills, especially practice and daily application.

As an instrument, we used the Assessment Protocol, which was piloted and refined based on feedback. It was distributed to professional school associates who monitored the adjustment of teaching during the pandemic and assessed the impact on children with various disabilities.

Strategies and approaches used in working with the child were evaluated: platforms, applications, parental mediation, summaries of materials, customized material, visually structures, symbols, Braille material, Daisy textbooks, assistive technology.

Then, assessment of developmental areas of progress and regression in children: emotions, behavior, interaction and communication, quality of knowledge, application in everyday life circumstances.

After that, academic progress and regression in: Montenegrin language, mathematics, English language, skills, natural and social sciences.

This was followed by an assessment of the areas in which the child needs to work additionally: learning, practicing, applying, collaborating, socializing, emotional exchange, communication and understanding, behavioral, self-care, treatment. Also, in what way: with individualized material, with catch up material, additional classes, individual work of a professional associate of the school, individual work of a member of the mobile team, individual treatments of associates of the resource center. Finally, what approach or technology should be used for future work with the child?

\section{Findings}

43 children were assessed and are dominated by intellectual and autism spectrum disorders, which correspond to the general education inclusive context.

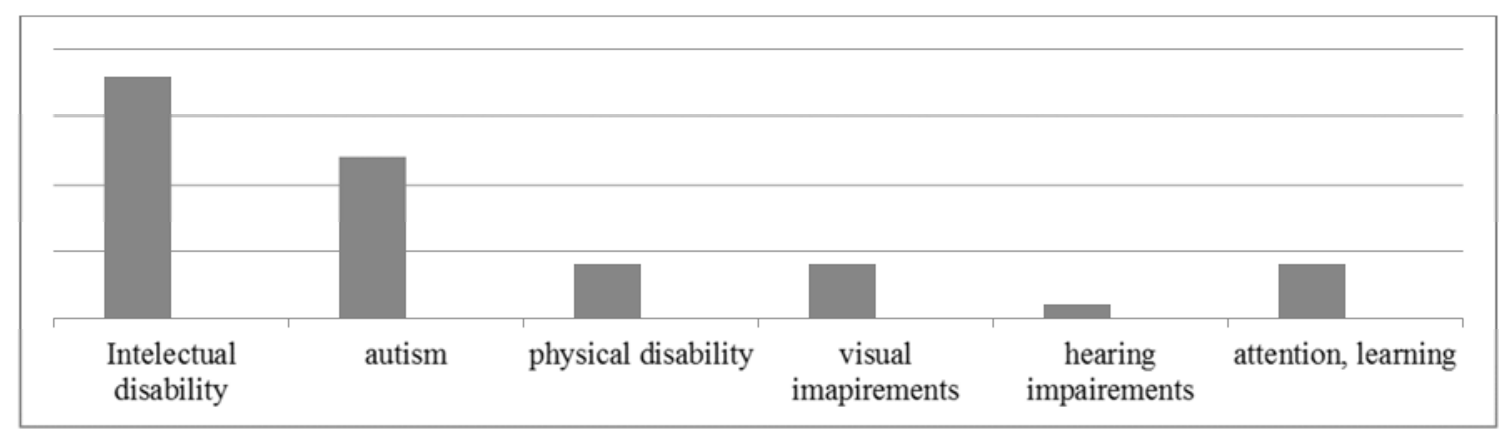

Figure 1. Children and disabilities.

Mostly children are from II, II, VII and VIII grades, the least from I and IX grades of primary school. This is because the first graders are still in the observation phase, for students of the IX, final, grade; an Individual Transition Plan (ITP) for the secondary school enrollment is being developed and implemented. 


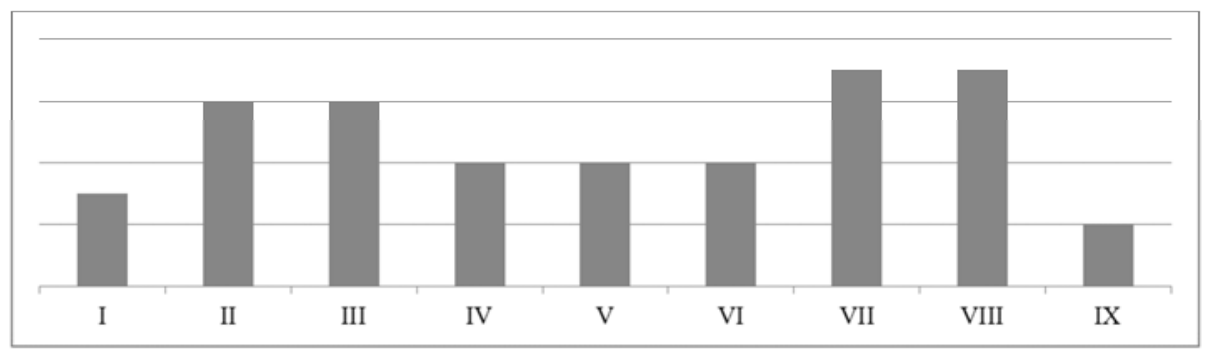

Figure 2. Children and grades.

Data about strategy and approach to work showed that platforms and applications were the least used, they mostly communicate via viber with the child or with the mediation of parents. That individualized, concise, adapted and visually adequate material is predominantly prepared. The less used are Braille materials and Daisy textbooks (although they have great potential for the widest range of disabilities and developmental difficulties).

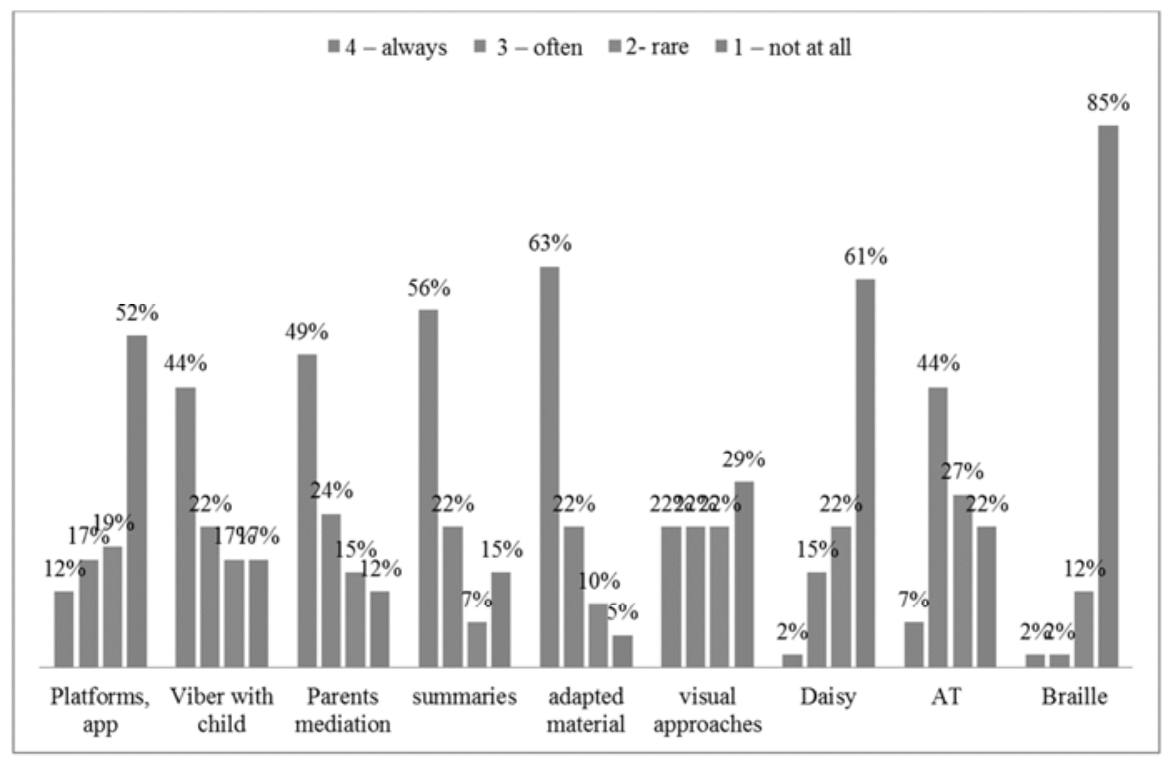

Figure 3. Working and communication strategies.

When it comes to developmental progress, it has been shown that children's emotionality is achieved to a large extent in $49 \%$ and $37 \%$ in a small extent. Then, the progress in behavior is 54\%. Regarding interaction and communication it happens that in some children it is present in a large $41 \%$, in some $37 \%$ in a small extent. The quality of knowledge is assessed as high by $41 \%$, or very small in $34 \%$, and that the application is small $-51 \%$ or absent $-20 \%$.

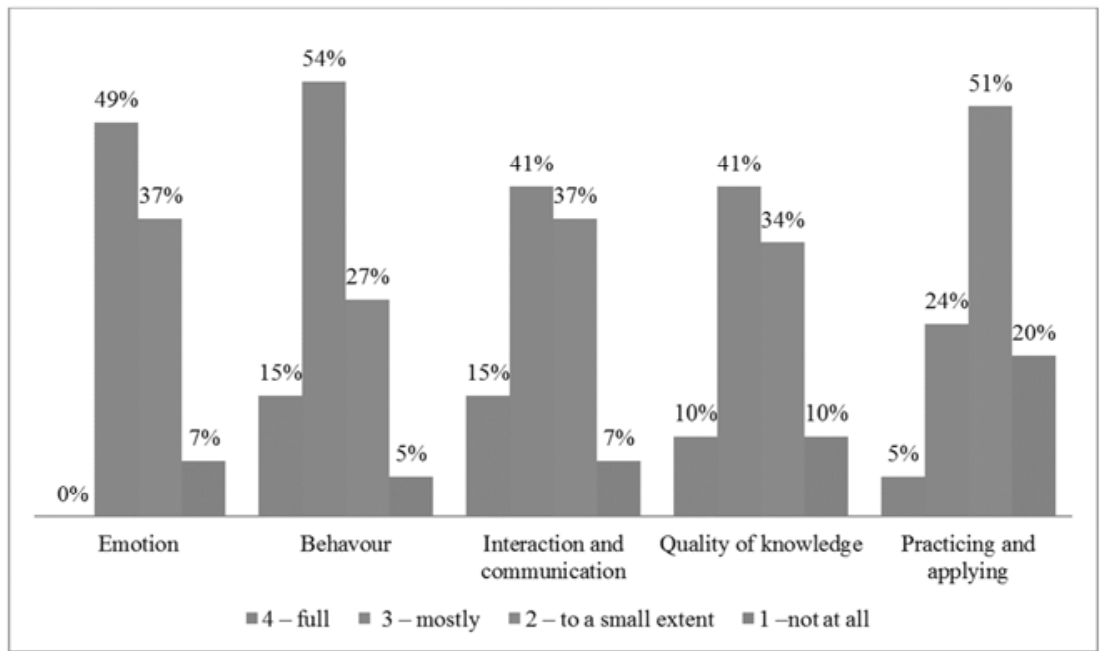

Figure 4. Developmental achievement. 
Regarding the areas in which, possibly, there happened developmental regression in $61 \%$ they estimate that there is no emotionality damages, which may be the result of increased parental presence and attachment, as well as strengthened individualized contact with teachers that makes child develops emotional affiliation. In terms of behavior, it is estimated that it depends on individual cases, experiences and disability, so that it is regressive in $29 \%, 41 \%$ in a small extent or $29 \%$ not at all. The situation is similar in the area of interaction - regression was observed in $29 \%$ of cases, slightly expressed in $41 \%$, not noticed at all in $29 \%$. For the quality of the knowledge, they believe that it is slightly impaired in $46 \%$, not at all in $29 \%$, but almost a quarter, more precisely $24 \%$, estimation is that it should be the subject of future attention. The area that has experienced the greatest regression is the practicing and application of the knowledge $41 \%$ to a large extent, which is related to the isolation and time spent in a home environment that suspends valuable practical experience.

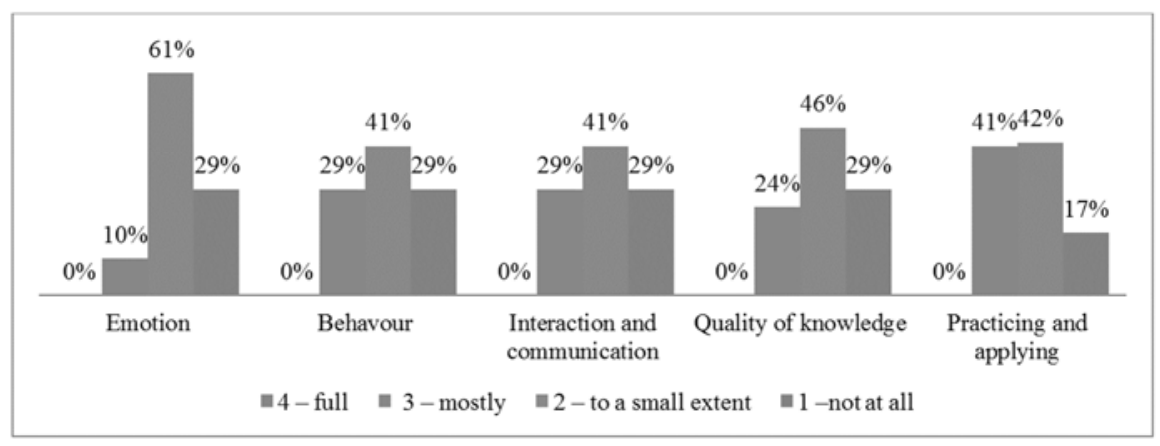

Figure 5. Developmental regression.

When it comes to academic achievement, respondents estimated that it's depending on child and disability. The greatest achievement is in the teaching of the Montenegrin language in $60 \%$, mathematics in $51 \%$. When it comes to the English language, progress is high at $39 \%$, but achieved in a small extent in $51 \%$ of cases. Skills (art, music, physical education) were achieved in $44 \%$, but in $46 \%$ to a small extent. The natural sciences achieved in a big extent $46 \%$, $41 \%$ to a small extent. Social sciences achieved in a big extent in $41 \%$ and $49 \%$ in a small extent.

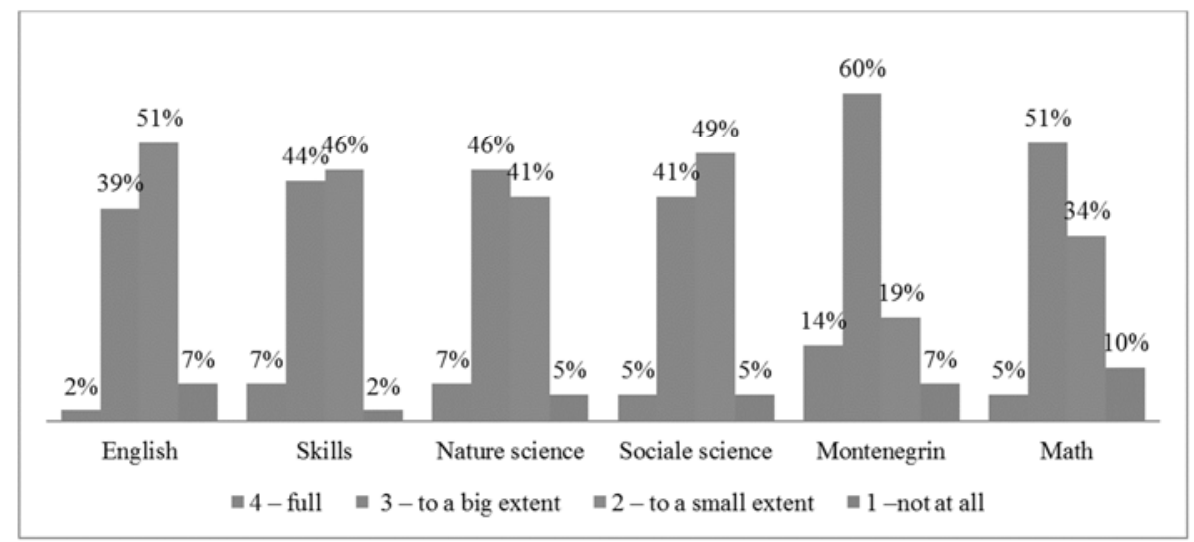

Figure 6. Academically achievement.

Assessment of a regression level in teaching and academic achievement shows that in more than half of the cases it is not conspicuously pronounced. Thus, skills most often appear as potential areas for future support - regression was observed in about $37 \%$ of cases, followed by teaching in the field of mathematics, where regression was estimated in about 34\%. We see the reasons because these are areas that require direct work, in vivo experience, encouragement, stimulation, abetment, instruction.

Regarding the areas that will need to be emphasized in future work, we get the following. One by one teaching should be fully in almost $22 \%$, in a high extent in $41 \%$. Then, the practical application assessed in $22 \%$, or in a high extent in a $51 \%$. Socialization is an area that is estimated that depend on the types and degrees of disability - in $22 \%$ are fully recommended to work on the participation and inclusion, $34 \%$ to a large extent, $27 \%$ to a small extent, and $17 \%$ not at all. Then, when it comes to emotional relations, an individualization of the approach will also be needed - for full focus it is provided in $19 \%$, for work to a large extent in $32 \%$, for a small extent $27 \%$, and not at all for $22 \%$. In communication and interaction, respondents express the importance of additional individual analyze, planning and organization: fully $29 \%$, to a large extent $32 \%$, to a small 
extent $24 \%$, not at all 14\%. Behavior is an area for which at this moment they did not have estimates of a high need for additional work - not at all is the answer in $41 \%$ - which may be due to the fact that they did not have live contact with these students. Respondents rate self-care as area that should be highlighted in the future - in a large extent in $41 \%$, to a small extent in $29 \%$. Treatments are preferred as important in the future fully in the $44 \%$, in a big extent in $17 \%$, in small extent in $27 \%$. not at all in $12 \%$ - these telling us that treatments depends on the child disability characteristics, their potential, the work done so far.

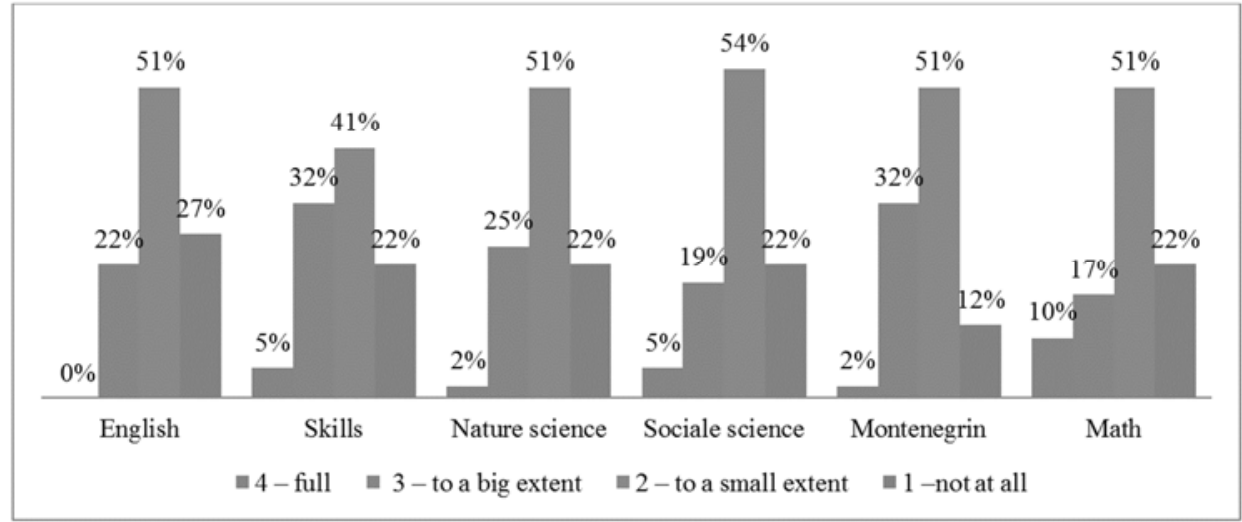

Figure 7. Academically regression.

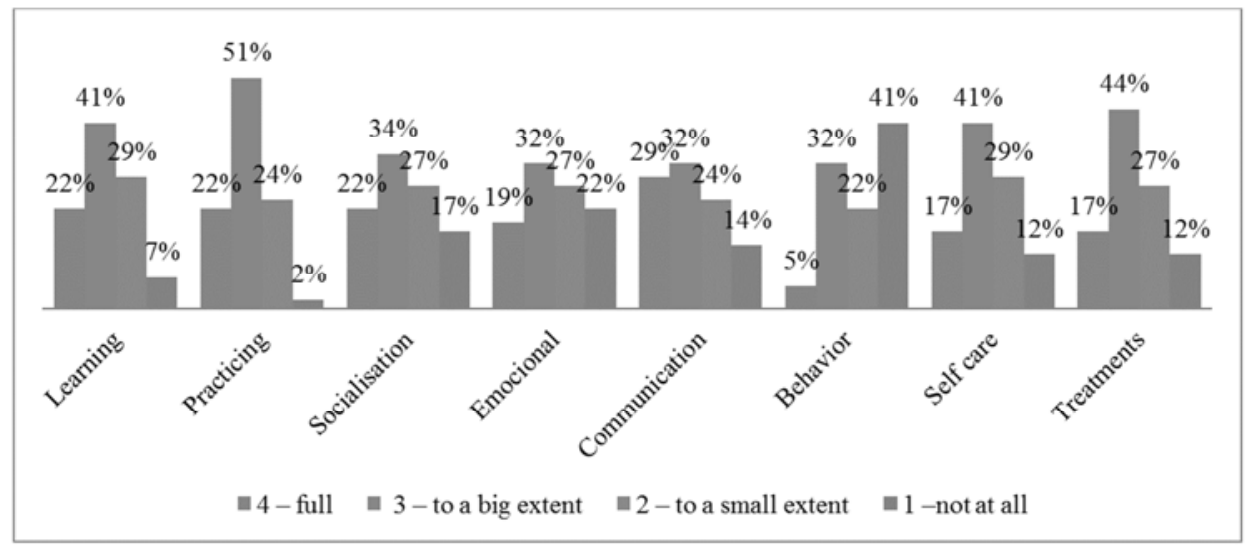

Figure 8. Areas for the additional work.

The respondents' assessment of how to work with the child is following. Individualized and catch up material is important constantly in $29 \%$, in a large extent in $41 \%$. Additional teaching is fully recommended in $29 \%$, in a large extent in $22 \%$ of cases. The most intensive work is expected from a professional associate of the school $-29 \%$ in full, to a large extent $37 \%$. Lower expectations are from the mobile team - 39\% sometimes, $15 \%$ not at all. The lowest expectations are from resource centers - 29\% sometimes, $32 \%$ not at all.

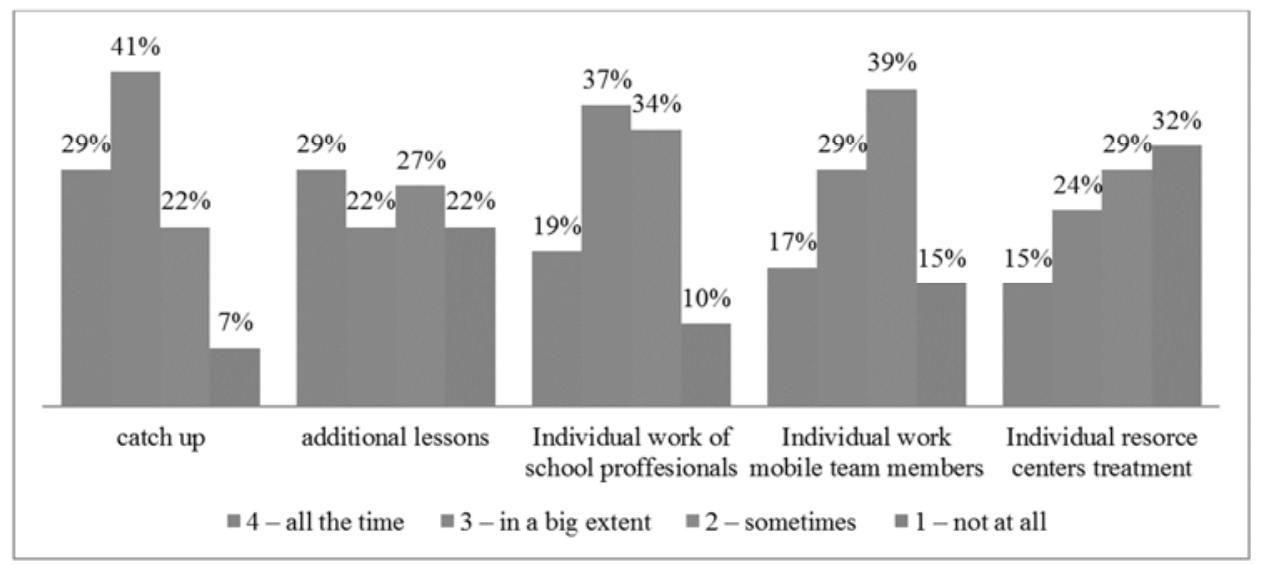

Figure 9. Measures for the additional work. 
As recommended strategies for future work, adjusted material is evaluated as the most desirable: fully $61 \%$. Then structures and schedules fully in $37 \%$, sometimes in $32 \%$; Visual approaches fully in $29 \%$, in $39 \%$ sometimes. Braille material is not at all needed in $66 \%$ (this shows teacher's knowledge of needs in relation to methods, disability). What they less assume are Daisy textbooks - rarely $49 \%$, not at all $22 \%$, or assistive and augmentative technology $-34 \%$ rarely, $10 \%$ not at all, which tells us about the need to further promote them.

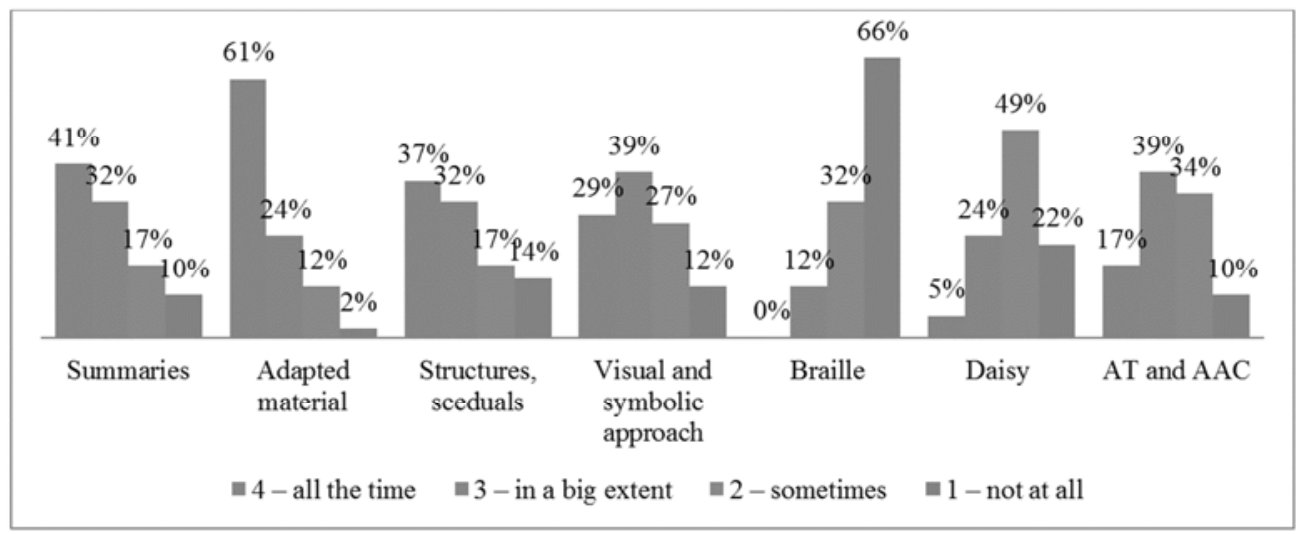

Figure 10. Approaches for the additional work.

\section{Conclusions}

The aim of the research was to determine the actual level of developmental and educational achievement of children with special educational needs in order to see to what extent the quality of their knowledge and competencies was affected by isolation and non-attendance due to the Covid 19 .

First of all, we conclude that the teachers decided to work and communicate via viber, with parents' participation because it is easier for the children with disabilities.

They were based on the adaptation and individualization of teaching and working materials based on the IDEP done for each child. We conclude that they know the didactic material significantly, but that some resources have not been used to a sufficient, justified and desirable extent - Daisy textbooks and assistive technology.

In relation to the impact on the children emotional status, we conclude that it was relatively maintained thanks to a more direct, individualized relationship. Children developed the impression that the teacher takes care of them personally. However, it will be important to organize forms of support when children find themselves in a real context again.

Parallel and consequent behavior is preserved in a significant number of children, appreciating each other's mutual orientation. However, there is significant percentage of students that need support in the future because they were influenced by restraint, inhibition, limitations.

Interaction and communication are the developmental areas in which in a significant number of children happened attachment, awareness because that they have enjoyed an individualized teacher orientation. But, it is at the same time estimated the presence of regression in this area. Interaction and communication are affected due to the fact that it took place in a different environment, under changed circumstances, and it will be important to strengthen these skills during future work.

When it comes to the quality of knowledge, it has been achieved in accordance with the set expectations thanks to the significant reductions in content, but at the same time it is a reason that it should be in further focus. Especially affected are practice and application because the teaching took place at home, not in a structured school environment, so this is an area that should be emphasized in the future.

Therefore, as academic areas that have the highest achievement are Montenegrin language and mathematics because they were most emphasized as so-called core subjects. On the other hand, the subject areas in which regression is manifested are foreign language, skills, natural and social sciences - it is because they require immediate work, experience, practice, encouragement.

Therefore, after the school beginning, the principle of individualization should be maintained, taking into account the characteristic of child disability, his potentials, and appropriate methods of work that teachers know relatively well, but they should be further strengthened to use them, especially in areas where the child needs support. Intensive work should be done on the catch up activities and materials, practical application, socialization, interaction, communication in a real context [13].

Additional support is most expected from the school professional associate, to whom they are most oriented, that better promotion and organization of the mobile service needed, as well as the resource centers services that are not equally accessible [14].

Finally, Daisy, assistive technologies, augmentative communication models should be promoted, important for the child functional and fully participation, learning, independence [5]. 


\section{References}

[1] Acedo, C., (2008), Inclusive education: pushing the boundaries. Prospects, 38, 5-13.

[2] AAIDD - American Association on Intellectual and Developmental Disabilities (2010). Intellectual disability: Definition, classification, and systems of supports. Washington, DC: American Association on Intellectual and Developmenal Disabilities.

[3] Carpenter M., Charlop-Christy, M., Le L., Leblanc L., Kellet K. (2002), Using the picture exchange communication system (PECS) with children with autism: assessment of PECS acquisition, speech, social-communicative behavior and problem behavior; Journal of Applied Behavior Analysis, 35 .

[4] Draffan, E. A., Predavanje: AT i AAC, set simbola i originalna AAC aplikacija, Korišćenje tehnologije 21. veka za promociju komunikacije, obrazovanja i socijalne inkluzije dece sa smetnjama u razvoju, 05-06. 06. 2019., ŠOSO "Milan Petrović", Novi Sad.

[5] Lazor M., Isakov M., Ivković N., (2012), Asistivna tehnologija u školi, Edicija Praktikum, Škola za osnovno i srednje obrazovanje "Milan Petrović", Novi Sad.

[6] Milić, T., Marić, A., Vuksanović, A., Popović, A., TrailovićŠljivančanin, A., Radulović, J., Popović, J. (2017) Instruktivno-edukativni materijal za inkluzivni rad i učenje đece $\mathrm{s}$ posebnim obrazovnim potrebama, Ministarstvo prosvjete, UNICEF, Podgorica.

[7] Milić T., Marić A., (2015) Priručnik za rad s đecom s autizmom, Zavod za udžbenike i nastavna sredstva, Podgorica. $7-10$.

[8] Muanović D., Novak J., (1998), Dete sa smetnjama u razvoju, Save the children, Beograd.

[9] Pešikan A., Lalović Z., (2017) Obrazovanje za život: ključne kompetencije za 21. vijek u kurikulumima u Crnoj Gori, Unicef, Podgorica, str. 36.

[10] Radulović J., Marić A., Milić T., Vešović-Ivanović A., Janković M., (2017), Priručnik za korišćenje Daisy udžbenika, Zavod za udžbenike i nastavna sredstva, Podgorica.

[11] Ćordić A., Bojanin S., (2011), Opšta defektološka dijagnostika, Zavod za udžbenike, Beograd.

[12] http://www.skolskiportal.edu.me/Pages/Inkluzivnoobrazovanj e.aspx

[13] UNICEF, (2020), Izgradnja na krizu otpornih obrazovnih sistema tokom i nakon pandemije COVIDA-19, Regionalna kancelarija UNICEF-a za Evropu i Centralnu Aziju, https://www.unicef.org/montenegro/izvjestaji/izgradnja-nakrizu-otpornih-obrazovnih-sistema-tokom-i-nakon-pandemijekovida-19

[14] UNICEF, (2020), Protecting children and adolescents with disabilities from the pandemic, https://www.unicef.org/eca/protecting-children-andadolescents-disabilities-pandemic

[15] WHO, (2020) Considerations for school-related public health measures in the context of COVID-19, https://www.who.int/publications/i/item/considerations-forschool-related-public-health-measures-in-the-context-ofcovid-19 